\title{
PROFESSORA ONDINA PEREIRA FOLDA (1923 - 2017): ITINERÁRIOS DE UMA EDUCADORA EM LARANJEIRAS DO SUL -PR.
}

Resumo: Situado no campo da História da Educação, este artigo relata a trajetória pessoal e profissional de Ondina Pereira Folda (1923 - 2017) destacando seu papel na área educacional de Laranjeiras do Sul-PR entre as décadas de 1940 a 1980. Em meados do século XX o isolamento da região, causado pela falta de estradas e incipientes meios de comunicação, agravava a precariedade de oportunidades educacionais e oferta de políticas públicas. $O$ objetivo deste trabalho é retratar os desafios pessoais e coletivos que a tornaram uma das mais relevantes educadoras do município numa perspectiva que ultrapassa as fronteiras da sala de aula e transcendem o fazer pedagógico. A metodologia utilizada é a revisão bibliográfica e análise de entrevistas e fontes documentais. Conclui-se que o apurado senso crítico e sensibilidade aos problemas sociais alicerçaram suas ações buscando a melhoria nas condições das escolas, ampliação da oferta educacional, formação adequada aos docentes e incentivo a atividades formativas para além dos espaços escolares.

Palavras-chave: biografia; conhecimento; Educação Escolar Pública; História da Educação.

\section{TEACHER ONDINA PEREIRA FOLDA (1923 - 2017): ITINERARIES OF AN EDUCATOR IN LARANJEIRAS DO SUL -PR.}

\begin{abstract}
Situated in the field of the History of Education, this article reports the personal and professional trajectory of Ondina Pereira Folda (1923 - 2017) highlighting his role in the educational area of Laranjeiras do Sul-PR between the 1940s and 1980s. In the middle of the 20th century, the isolation of the region, caused by the lack of roads and incipient media, aggravated the precariousness of educational opportunities and the offer of public policies. The objective of this work is to portray the personal and collective challenges that made it one of the most relevant educators of the municipality in a perspective that goes beyond the boundaries of the classroom and transcend the pedagogical work. The methodology used is bibliographic review and analysis of interviews and documentary sources. It is concluded that the sharp critical sense and sensitivity to social problems have based their actions seeking to improve the conditions of schools, expand the educational offer, adequate training for teachers and encourage training activities beyond school spaces.
\end{abstract}

Keywords: biography; knowledge; Public School Education; History of Education.

\section{Introdução}

A partir de 1920 iniciou-se, no Brasil, um processo de profundas transformações políticas, econômicas e sociais com maior participação das camadas populares na tomada de decisões. Esse movimento se intensificou na década de 1930 com as modificações nas relações de trabalho ocasionadas pela passagem da sociedade agroexportadora para a sociedade urbana industrial alicerçada na produção de bens de consumo. Essas alterações no mundo do trabalho, complexificaram as relações em todas as esferas e geraram, por consequência, necessidades na

1 Pedagoga na Universidade Federal da Fronteira Sul (UFFS) - campus Laranjeiras do Sul- PR. Mestra em Educação pela Universidade Estadual do Oeste do Paraná (UNIOESTE) campus Francisco Beltrão - PR. Doutoranda em Educação pela Universidade Federal de Santa Catarina (UFSC) campus Florianópolis - SC. luspassin@uffs.edu.br 
área educacional que fizeram repensar a função social da escola. Desde a Proclamação da República, havia o entendimento de que a escolarização mínima era fundamental para o desenvolvimento econômico e também contribuiria para diminuir as desigualdades sociais no país. A partir do lançamento do Manifesto dos Pioneiros, no ano de 1932, a educação brasileira passou a ser objeto de debate entre educadores, intelectuais, políticos e população provocando mudanças na legislação e nas políticas educacionais. O Manifesto, redigido por Fernando de Azevedo, sintetizava o pensamento de educadores e pesquisadores de várias áreas e, devido a sua importância, pode ser considerado um divisor de águas para a educação brasileira.

Concordamos com Borges quando a autora afirma que "o ser humano existe somente dentro de uma rede de relações” (p. 222, 2008). Essa constatação ratifica o papel do indivíduo no movimento real da história ao contrário da concepção positivista que enfatiza heróis e líderes políticos: todos produzem história. No caso dos educadores, foram eles que, motivados pelo desejo de ampliar e melhorar o nível de educação formal que era oferecido no seu entorno, mobilizaram colegas, políticos e comunidade em prol de uma causa maior: a educação. Portanto, este cotidiano com histórias cheias de singularidade, de fazer pedagógico e questionamentos acerca da legislação e do pensamento educacional vigente mescla-se com a história dos lugarejos e cidades estabelecendo relações mais amplas com a sociedade.

Sob esta perspectiva relata-se a trajetória pessoal e profissional da professora Ondina Pereira Folda (1923 - 2017), nascida catarinense, mas paranaense por artimanhas da História, destacando o protagonismo exercido por ela na organização, estruturação e ampliação das condições educacionais no município de Laranjeiras do Sul - PR. Enfatiza-se o período compreendido entre as décadas de 1940 a 1980 sob forma de narrativa biográfica que busca reconstituir aspectos relevantes de sua história desde o nascimento, perpassando por seus percursos de formação - na educação primária, secundária e superior - e pelas significativas influências de diálogos com os pares até a continuidade da busca pelo aprendizado pós aposentadoria. Para isso e, buscando contextualizar a região e o país nos aspectos econômico, político, social, educacional e cultural, nos reportamos a trabalhos de estudiosos da historiografia da educação como Tanuri (2000), Lemiechek (2014) e Miguel (2016); à legislação do período; entrevistas e fontes documentais organizadas e disponibilizadas em forma de dossiê pela família Folda (2020).

Este texto é uma versão revista e ampliada do trabalho publicado nos anais do "I Seminário Estadual - A Pedagogia Histórico-crítica e a educação pública paranaense: 30 anos do 
currículo básico" promovido pela Universidade Estadual do Oeste do Paraná (UNIOESTE) Campus Francisco Beltrão - PR. Para facilitar a fruição na leitura e, pela natureza biográfica, optamos por escrevê-lo em sequência cronológica assim estruturado: primeiramente explanaremos sobre a infância e adolescência da professora Ondina até o início formal de sua carreira e chegada ao município de Laranjeiras do Sul - PR. Em seguida, o enfoque é dado sobre seu protagonismo nas atividades da Escola Normal Regional Floriano Peixoto e Escola Normal Colegial Dr. Leôncio Correia. A seção seguinte se mescla e complementa a anterior abordando como, na condição de mentora intelectual de jovens e adultos, criou condições e espaços extraclasse para a realização de atividades esportivas, artísticas e culturais que marcaram intensa e positivamente a comunidade. Finalizando, destaca-se a eterna busca pelo conhecimento mesmo após a sua aposentadoria no magistério no ano de 1981.

\section{Do nascimento à mudança para Laranjeiras do Sul}

Num contexto de grande efervescência do Brasil dos anos 1920, com intensas transformações sociais, culturais e políticas, mobilizações e revoluções lideradas por civis e militares, além de eventos importantes como a Semana de Arte Moderna (1922) nasce Ondina Pereira no dia 25 de janeiro de 1923 em Porto União - SC. Filha de Pordentina da Silva Pereira e Amaro Pereira, tinha 7 irmãos: Maria Benta, Landolina, Nelina, Julieta, Bernardino, Valmor e Noraldino. No ano de 1927 a família de sitiantes e tropeiros muda-se para o município de Cruz Machado - PR vivendo naquele local até 1929 quando estabeleceu-se definitivamente em Guarapuava, no mesmo estado.

Movida, desde a infância, por um grande desejo de aprender, foi alfabetizada aos 6 anos por suas irmãs mais velhas que eram professoras. Segundo Folda (2020) nessa época, Guarapuava ainda recebia os trabalhos missionários da Igreja Católica, que ocorriam em diversas regiões do mundo. Nesse município, atuavam padres e irmãs da congregação idealizada na segunda metade do Século XIX pelo missionário Arnaldo Janssen em Steyl, território holandês. Com a contribuição de outros religiosos o então missionário Arnaldo Janssen, hoje Santo canonizado, fundou a congregação dos Missionários do Verbo Divino para padres e irmãos, bem como a congregação das Missionárias Servas do Espírito Santo para madres e irmãs. Foi junto a esta congregação que Ondina iniciou sua vida acadêmica formal.

Em 1930 foi matriculada no Educandário Nossa Senhora de Belém fundado em 07 de maio de 1907 pelas irmãs da Congregação Missionárias Servas do Espírito Santo. Mais tarde 
este estabelecimento passou a denominar-se Colégio Nossa Senhora de Belém, e está ativo até os dias de hoje. Concluiu, no ano de 1934, as cinco séries exigidas ao ensino primário na época. É importante salientar que o brilhantismo, a dedicação e o excelente desempenho nas disciplinas isentou os pais do pagamento das mensalidades recebendo Ondina, desta forma, uma bolsa de estudos no referido educandário. De acordo com o dossiê escrito por Folda, Detzel e Klein

Ondina, desde os 7 anos, percorria a pé $12 \mathrm{~km}$ diários para perfazer o trajeto de ida e volta à escola, atravessando os campos gelados de Guarapuava com seus ventos cortantes nas manhãs de inverno rigoroso e, em tempos de chuva, não raro levando os sapatinhos nas mãos para não molharem ao atravessar áreas alagadiças dos carreiros que precisava percorrer. Em sua companhia iam seus dois irmãos menores Valmor e Noraldino, os quais eram carregados no colo para atravessar as sangas e alagados e não molharem seus calçados. No caminho, iam distribuindo o leite que a família vendia a moradores da região. Assim, além do embornal com caderno e livros, também carregavam cada um seu alforje que podia comportar até 8 litros e, na volta, passavam recolhendoos. As dificuldades de acesso, contraditoriamente, pareciam funcionar como impulso para mais dedicação aos estudos e assim concluiu os cinco anos primários $(\mathrm{p} .04,2020)$.

Ao findar a primeira etapa da escolarização, Ondina não apenas tinha domínio pleno de conceitos matemáticos, mas realizava mentalmente cálculos de juros simples e compostos e outros de maior complexidade. Em entrevista concedida a esta autora, em 27 de maio de 2014, relatou um episódio que demonstra a referência que era para os colegas de magistério até mesmo quando aqueles possuíam nível de educação formal mais elevado que o seu. No episódio narrado por Ondina, uma colega pedia ajuda acerca de uma banca avaliadora de exames finais discentes. As professoras estabeleceram o seguinte diálogo:

Escute uma coisa...tem um desenho lá no quadro e uma continha que diz assim: dê um número decimal equivalente a 1/4. Eu disse: pois é 25 centésimos, dona Maria2. É mesmo? Tem certeza? Falei: tenho. Então? Não sabia melhor que ela? Porque eu tinha a prática, porque em Guarapuava quando eu fiz aquele concurso eu tirei 95 e naquele tempo eu era nova, nossa, meninota. Eu estudava! As irmãs, eu fui direto pro colégio, fiquei lá as férias todas. Elas me traziam aqueles negócios de geometria tudo me explicando base $\mathrm{x}$ altura dividido por 2. Eu tava afiadíssima! (FOLDA, 2014)

Embora demonstrasse aptidão para diversas ciências, destacou-se durante toda sua vida pela capacidade excepcional para leitura, memorização de textos, letras de músicas e poesias

2 Nome fictício a fim de preservar a identidade da interlocutora. 
tornando-se exímia declamadora e amante da literatura, além do gosto e contínuo aprendizado de línguas estrangeiras.

O contato com as freiras e a Igreja Católica seria essencial e orientaria, ao longo da vida, sua conduta, caráter, postura, valores, a forma de relacionar-se com o outro e o desempenho de suas atividades profissionais. Este reconhecimento pelo trabalho das religiosas fica explícito em momentos como o relatado a seguir em uma conversa entre Ondina e sua professora de piano, Cibele Rachel Manzochi Assmé

Veja, tudo isso que eu tenho, o piano, um lar, o cafezinho que posso lhe servir depois da nossa aula, enfim tudo o que tenho e sou, eu devo à Igreja Católica. Porque na minha infância foi essa instituição que me deu a oportunidade do aprendizado formal, através das Irmãs do Educandário e, especialmente, do Padre Theodoro Matessi missionário italiano do Verbo Divino, os Verbitas. Ele, ainda jovem, sabendo que as crianças eram muito pobres e que iam para o colégio sem se alimentar, promovia, com carinho, brincadeiras pedagógicas que aplacavam a fome das crianças estimulando-as a aprender ainda mais, porém de forma que não se sentissem humilhadas e sim importantes naquele processo. Essa forma carinhosa consistia na chegada festiva do padre ao pátio da escola carregando um cesto cheio de pão quentinho e abundantemente recheado de carne assada bem temperadinha que exalava um cheiro muito bom. Para ganhar o pão com carne, ele fazia uma festa chamando a criançada com o cesto de pães em uma das mãos e, na outra, um sino que era sacudido vigorosamente. Então, a brincadeira de todo dia era entregar o pão somente para quem acertava as perguntas que ele fazia sobre diversas matérias, no entanto, se a criança errava, nova oportunidade era dada até que acertasse para levar seu o pão, de forma que todas tinham essa oportunidade. [..] Eu entendo que essa era uma forma muito carinhosa e cuidadosa para que nenhuma criança se sentisse humilhada ao receber friamente um pão como se fosse uma esmola. O pão era um prêmio! O prêmio pelo acerto como resultado do esforço em estudar e aprender. Dessa forma, valorizava a criança como ser humano e a escola como caminho para o crescimento pessoal (FOLDA, DETZEL e KLEIN, p. 26, 2020).

O encontro de Ondina com o magistério aconteceu em 1936 quando tinha 12 anos de idade. Nas fazendas, ministrava aulas particulares alfabetizando filhos e filhas de fazendeiros e de empregados. De acordo com relatos à família este fora um período bastante difícil com precárias condições de trabalho. Por vezes passara fome e frio na casa dos patrões, longe da família. Tais dificuldades, não a fizeram desistir, pois acreditava que a prática pedagógica era necessária para qualificá-la profissionalmente. Esta prática seria fundamental para que em 1938, aos 14 anos, recebesse da Prefeitura de Guarapuava o documento com sua nomeação como professora primária. Acerca da entrada precoce no magistério, em entrevista, Ondina mostrou sua espirituosidade e bom humor, traço marcante de sua personalidade, ao dizer: "ela saiu da sala 
e disse pra mim: Dona Ondina! Porque eu sempre fui a dona. Fiquei velha desde criança. Professora com 14 anos e já era Dona Ondina” (FOLDA, 2014).

$\mathrm{Na}$ época, a legislação educacional estava se estruturando não havendo obrigatoriedade do diploma de curso normal para o exercício da profissão docente. Assim, em 1941, prestou concurso público estadual para o magistério conquistando nota geral superior a 9,0 e "recebeu das mãos do então interventor federal, Manoel Ribas, com os demais aprovados, a Portaria de nomeação em evento no qual ouviu elogios do interventor pelo feito de ter conquistado o primeiro lugar no concurso" (FOLDA, DETZEL e KLEIN, p. 04, 2020).

O casamento com Thadeu Folda aconteceu no dia 19 de junho de 1943 em Guarapuava e ele seria o companheiro da vida e com o qual teria seus 8 filhos: Laura, Heron Luiz, Begail, Lúcia Maria, Léo Thadeu, Lígia Regina, Lorena e Lorena Carmen. O casal, sempre animado, cultivava o gosto pela arte e cultura não perdendo a oportunidade de viajar para conhecer pessoas, lugares e diferentes culturas, ir a teatros, cinemas e frequentar bailes e festas. Thadeu Folda (1915 - 1986) possuía como grau de instrução formal o antigo ensino primário, obtido ao longo de 5 anos em escola de língua polonesa e era dotado de grande capacidade cognitiva e autodidata em muitos temas. Falava fluentemente quatro idiomas e compreendia bem outros dois, inclusive o Guarani usado para mediar conflitos entre indígenas e colonos na função de juiz de paz; realizava operações matemáticas complexas e possuía grande capacidade em compreender questões mais profundas e conceitos que envolviam história, política, geografia, ecologia. Durante sua vida exerceu profissões como comerciário, barbeiro, alfaiate, comerciante, juiz de paz e servidor público do INCRA função na qual se aposentou. Foi eleito para o cargo de vereador, no município de Laranjeiras do Sul por dois mandatos. 
Imagem 1- Thadeu e Ondina Folda no início da década de 1940

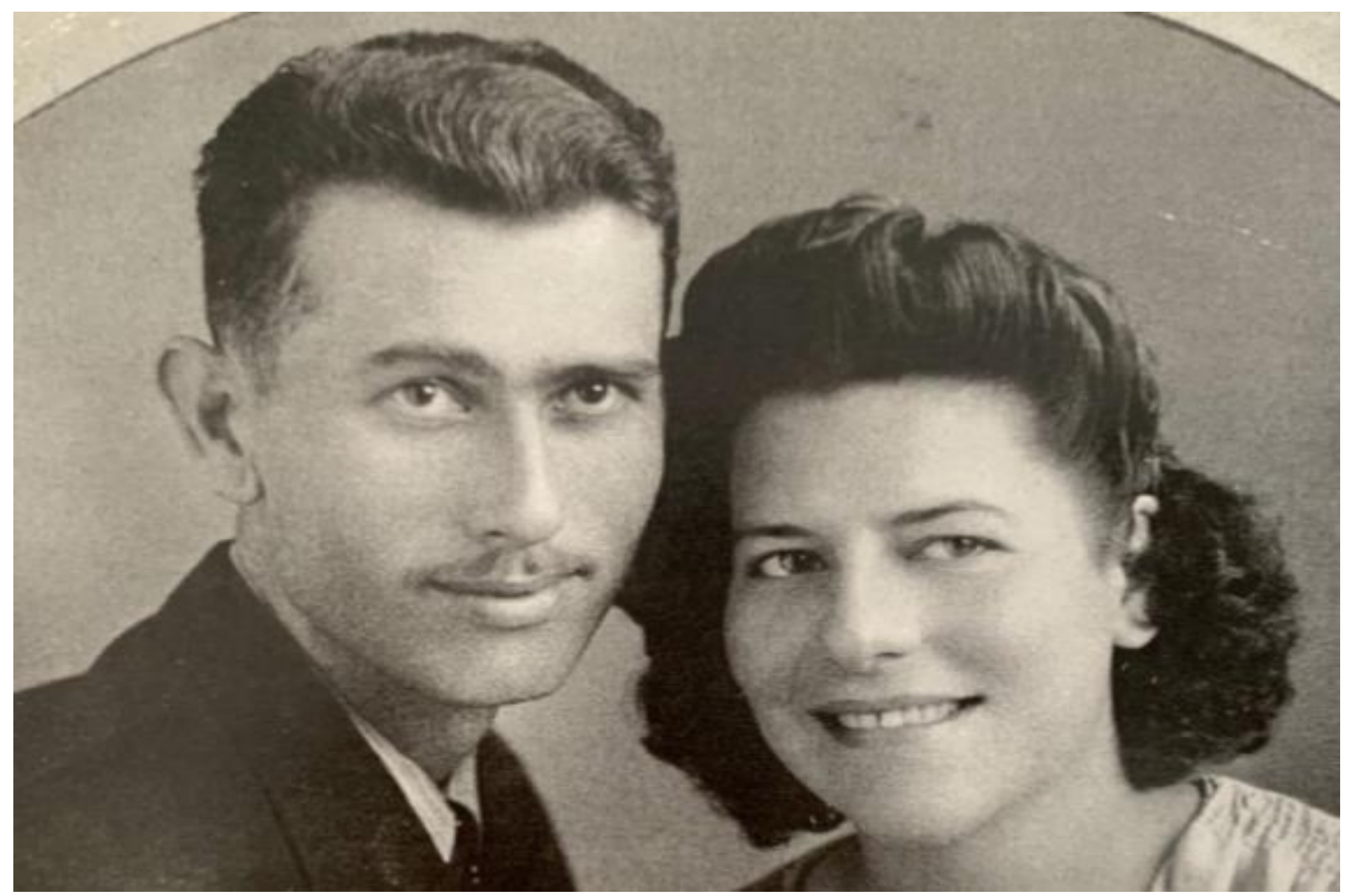

Fonte: acervo da família Folda

Para compreender os motivos que levaram a família de Thadeu e Ondina a mudar-se para Laranjeiras do Sul no ano de 1944 quando Laura, a filha mais velha do casal tinha apenas 28 dias de vida, é necessário contextualizar aquele período histórico marcado pelo andamento da II Guerra Mundial. Segundo Lemiechek (2014), Getúlio Vargas tomou posse em novembro de 1930 e durante aquela década articulou-se politicamente para garantir a interiorização do país criando a chamada Marcha para Oeste. Este programa tinha como meta o avanço do capitalismo industrial alicerçado na integração econômica de todo o território brasileiro. Fazendo parte deste programa, o Território Federal do Iguaçu foi criado pelo Decreto-Lei $\mathrm{n}^{\circ} 5.812$, de 13 de setembro de 1943 e abrangia o Oeste e Sudoeste do Paraná e Oeste de Santa Catarina. Dividido inicialmente em quatro municípios seus limites foram revistos surgindo Iguaçu (Vila de Xagu ou ex-Laranjeiras, distrito de Guarapuava) que foi elevada à categoria de município e capital ao mesmo tempo.

O Território teve dois governadores: o paranaense João Garcez do Nascimento, nomeado em janeiro de 1944, e o carioca Frederico Trotta empossado pelo presidente Eurico Gaspar Dutra 
em fevereiro de 1946 no contexto de pós-guerra. Embora a vida do Território tenha sido efêmera, a expectativa gerada pelo progresso ocasionado por sua criação foi essencial para moradores e migrantes que buscavam boa qualidade de vida com a possibilidade de usufruir de melhores serviços públicos como segurança, saúde, educação, transporte e comunicação. Assim, atraída pelas oportunidades que se apresentavam, no ano de 1944 a família Folda chegou à nova capital.

\section{O Curso Normal Regional e a Escola Normal Colegial Dr. Leôncio Correia}

Na década de 1940, com a sociedade se reestruturando e a feminização do magistério despontando, a formação de professores se mostrou imprescindível: mudanças na legislação e políticas públicas se faziam necessárias. Em 1930 Vargas havia criado o Ministério da Educação e Saúde Pública confiando o cargo a Gustavo Capanema que ficou célebre pelas reformas conhecidas como Reforma Capanema ou Leis Orgânicas: um conjunto de oito decretos-leis editados entre 1942 a 1946 abrangendo os ramos do primário e do ensino secundário. Destacamos, assim, a Lei Orgânica do Ensino Primário (Decreto-Lei ${ }^{\circ}{ }^{\circ}$ 8.529/1946) e a Lei Orgânica do Ensino Normal (Decreto-Lei n 8.530/1946) promulgadas em 02 de janeiro de 1946, considerando sua forte relação de interdependência.

Por mais que apresentasse falhas, a Lei Orgânica do Ensino Primário permitiu avanços na organização daquela etapa pois previa gratuidade e obrigatoriedade que exerceram forte pressão sobre a formação de professores, ampliando a abertura de Escolas Normais. Com o Decreto-Lei $\mathrm{n}^{\circ}$ 8.530, a Escola Normal foi dividida em dois ciclos: o dos regentes e o dos professores primários. Desta forma, o Curso Normal Regional habilitaria regentes para o ensino primário em escolas isoladas que, conforme descritas na lei, eram as que possuíam apenas uma turma e um professor, funcionando de forma multisseriada e majoritariamente na zona rural. Por outro lado, o Curso Normal Secundário habilitaria professores primários (BRASIL, Decreto-Lei $\mathrm{n}^{\circ} 8.530$, 1946).

A lei em questão, trazia inúmeros requisitos para o ingresso de estudantes. O parágrafo único do artigo 21 determinava: "Não serão admitidos em qualquer dos dois cursos, candidatos maiores de vinte e cinco anos" (idem, 1946). O fato é que as instituições do município não seguiram a lei. A professora Ondina é um exemplo pois ingressou no Curso Normal Regional em 1946 quando tinha 23 anos (dentro da idade limite) mas iniciaria o Curso Normal Secundário em 1958, aos 35 anos de idade. Pelo seu depoimento, inferimos que o caso dela não foi exceção, pois afirmou em entrevista que as normalistas: “[...] já não eram meninas. Eram professoras de 
sala de aula" (FOLDA, 2014). Nesta fala da professora Ondina evidencia-se um elemento que permeou a educação brasileira a partir do final do século XVIII estendendo-se ao longo do século XX e com significativa importância na educação laranjeirense: a feminização do magistério. Segundo Tanuri

A ideia de que a educação da infância deveria ser-lhe atribuída, uma vez que era o prolongamento do seu papel de mãe e da atividade educadora que já exercia em casa, começava a ser defendida por pensadores e políticos. De um lado, o magistério era a única profissão que conciliava as funções domésticas da mulher, tradicionalmente cultivadas, os preconceitos que bloqueavam a sua profissionalização, com o movimento em favor de sua ilustração, já iniciado nos anos 1970. De outra parte, o magistério feminino apresentava-se como solução para o problema da mão de obra para a escola primária, pouco procurada pelo elemento masculino em vista da reduzida remuneração (p. 66, 2000).

Quando Frederico Trotta foi nomeado governador do Território Federal do Iguaçu, no início de 1946, montou sua equipe de trabalho com muitos servidores federais vindos da capital, na época o Rio de Janeiro. Confiou a tarefa de condução da Divisão de Educação a sua esposa Laudímia. De acordo com Lemiechek

Sua nomeação era perfeitamente justificável pois, na época, ela contava com 25 anos de serviços prestados à Educação tanto na cidade de Curitiba como no Rio de Janeiro. Durante esse tempo, exercera funções como professora primária, diretora de grupo escolar, Fiscal e Orientadora de Ensino e Superintendente de Educação Primária do Distrito Federal. Era conhecida nos meios educacionais do país, pois havia feito parte da equipe do educador Anísio Teixeira quando este exerceu os cargos de Diretor do Departamento de Educação e Secretário de Educação e Cultura do Rio de Janeiro entre os anos de 1931 a 1935 (2014, p. 120 e 121).

Em Iguaçu, Laudímia foi diretora do Departamento de Educação no período entre março a setembro de 1946 e sua passagem foi muito significativa para a educação básica da região. Segundo Lopes, no início de suas atividades ela teria encontrado as escolas

[...] quase todas instaladas em péssimas condições: casebres, choupanas, capelinhas. E que os Grupos Escolares, em prédios territoriais, municipais ou alugados, necessitavam de consertos, ampliações, pinturas, construção de reservados e instalações de água. O mobiliário escolar como cadeiras, armários, e quadros-negros só existiam nos Grupos Escolares construídos no primeiro governo. As Escolas Isoladas só possuíam mesas toscas, bancos improvisados em caixotes, tocos e banquinhos. O material escolar era guardado em caixotes ou empilhado no chão. Conta que foram tomadas as devidas providências. Segundo a Diretora de Educação, todos os estabelecimentos de ensino estavam desfalcados de material escolar e livros pois "a dificuldade de transporte e o acúmulo de trabalho do Almoxarifado Geral perturbava a entrega do material". 
Ela diz ainda que, no decorrer de dois meses, foi feita uma grande remessa de material diretamente aos professores, cuja quantidade daria para os anos de 1946 e 1947 (2002, p. 153, aspas no original).

Para além desta situação de precariedade material havia o problema do fazer pedagógico fruto da inexistência da oferta de formação de professores na região. Laudímia afirmou, em relatório enviado ao presidente, que "[...] sendo fraquíssimo o professor, é fácil calcular a deficiência do ensino. [...] A nossa língua é ensinada de maneira deturpada, os alunos e professores têm um vocabulário paupérrimo, entremeado de termos estrangeiros" (LOPES, 2002, p. 153). A metodologia empregada pelos professores em 1946 pode ser resumida nas palavras de Laudímia:

Em uma das primeiras visitas que fiz a um Grupo Escolar, chamou-me a atenção uma espécie de ladainha que vinha de uma aula próxima do Gabinete da Diretoria. Pensei ser aula de Religião. Uma aluna lia uma página do caderno onde copiara o ponto Capitanias Hereditárias e a classe toda repetia o que ouvia! Conversei com a professora mostrando o inconveniente do processo e para convencê-la interroguei vários alunos sobre o que decoravam, não obtendo resposta que provassem ter entendido o que repetiam como papagaios (BRASIL, Território Federal do Iguaçu, 1947, p. 62).

Considerando o estado em que se encontravam as escolas da região e a metodologia empregada pelos professores, o investimento na reestruturação material e na formação docente seria de extrema importância para elevar a qualidade de ensino no Território. Desta forma, o Curso Normal Regional, apontado como o mais relevante investimento na área educacional do Território Federal do Iguaçu, foi criado pelo Decreto ${ }^{\circ} 2$ de 21 de abril de 1946 e, conforme visto anteriormente, fazia parte do projeto de expansão das Escolas Normais Regionais após a promulgação da Lei Orgânica do Ensino Normal.

Quando o Curso Normal Regional foi criado, Ondina já trabalhava como professora leiga na única escola primária da zona urbana de Iguaçu: o Grupo Escolar Tiradentes. Sua passagem pelo Curso Normal Regional merece destaque pela particularidade como ocorreu. De acordo com Lemiechek, conduzida por Laudímia Trotta e sua equipe, a triagem para ingresso no curso

caracterizou-se também como uma seleção para nivelamento em razão da heterogeneidade apresentada na formação dos candidatos aprovados na primeira avaliação considerando a necessidade premente de professores formados para atuar nos municípios e vilas do Território (2014, p.188 e 189).

Nas palavras de Ondina “[...] era tipo uma emergência. Porque era sertão, criaram o Território e não tinha professores. Então eles pegaram quem tivesse uma certa capacidade e iam 
fazendo exames" (FOLDA, 2014). A professora Ondina passou por este processo de aceleração formando-se no Curso Normal Regional em 1946.

Por ocasião de visita oficial da Chefe da Divisão de Educação do Território do Iguaçu, Sra. Laudímia Trotta, os alunos foram convidados a participar da seleção para escrita e pronunciamento do discurso de recepção àquela autoridade. O discurso elaborado por Ondina foi o escolhido e, ao proferi-lo, despertou a atenção da Sra. Trotta pela qualidade do texto, a ponto desta senhora recomendar à Direção da escola que submetesse a aluna a um exame de readequação de série. Realizando-se o exame, Ondina foi considerada apta para cursar de imediato a última série do curso. Assim, prestou avaliação dos conteúdos referentes às quatro séries do Regional e foi aprovada, concluindo o curso em apenas um ano (FOLDA, DETZEL e KLEIN, p. 5 e 6, 2020).

Imagem 2 - Normalistas acompanhados pelas professoras Laudímia Trotta e Jandira Coutinho e pelo governador Frederico Trotta em 1946

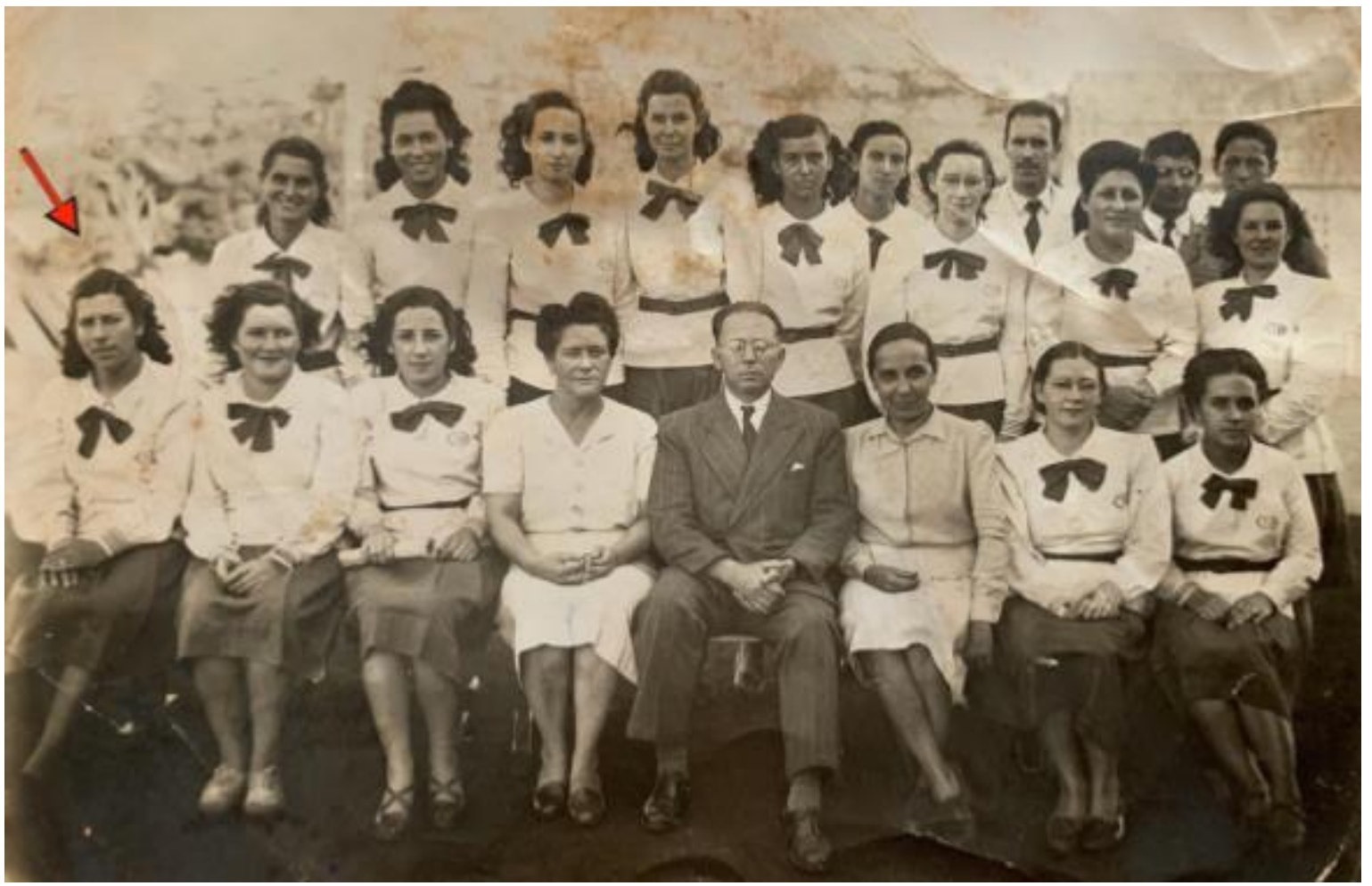

Fonte: acervo da família Folda

Extinto o Território Federal do Iguaçu, em setembro de 1946, e com a instabilidade atingindo a todos, foi grande a movimentação de pessoas que partiam da antiga capital, Iguaçu. De acordo com Lemiechek (2014), em 1947 o Curso Normal Regional não ofertou turmas. Porém, esta realidade se alterou no ano seguinte quando Moysés Lupion, governador do Estado do Paraná, sancionou a Lei Estadual n 41, de 20 de janeiro de 1948, criando a Escola Normal 
Ginasial Floriano Peixoto que foi instalada em 02 de março daquele ano. Ainda em 1948, a professora Ondina iniciou sua carreira como docente na instituição lecionando, no decorrer dos anos, disciplinas como Didática e Prática de Ensino. É lembrada por seus alunos como uma professora que inovava sua prática pedagógica, refletia sobre as particularidades e diferentes modos e ritmos de aprendizagem de seus educandos, preocupando-se com as relações entre professor e aluno e entre o ensino e a aprendizagem.

Ondina fez parte de um grupo que se mobilizou para a criação da Escola Normal Secundária e este empenho coletivo avançaria pela década de 1950 alcançando êxito apenas no ano de 1957. Ondina esteve presente nestes momentos de luta sendo diretamente interessada na sua criação considerando que não possuía aquele grau de ensino. Para Lemiechek havia

uma lacuna educacional de uma década em que os concluintes do nível ginasial ficaram sem estudar ou tiveram que se deslocar para outros municípios. Essa situação obviamente prejudicava as famílias economicamente desfavorecidas. Havia ainda a necessidade de formar professores num grau mais elevado de ensino (p. 141, 2014).

Para a mesma autora

A Escola Normal Colegial foi fruto da aspiração de muitos educadores e líderes políticos do município de Laranjeiras do Sul.[...] Entre essas pessoas, podemos citar os professores Amantino Carlos Stephanes, Sebastiana Maria Vieira e Ondina Pereira Folda. O ex-prefeito Arival Natel de Camargo também foi um dos incentivadores e, com o advogado Gilson Carvalho, que foi o primeiro diretor da instituição, propôs um projeto para a criação de um estabelecimento que atendesse o segundo ciclo de formação de professores (idem, p. 142, 2014).

Após quase uma década de luta e, fruto consolidado de uma construção coletiva, a Escola Normal Secundária de Laranjeiras do Sul foi criada pelo Decreto $\mathrm{n}^{\circ} 11.292$ de 11 de julho de 1957. No entanto, a solenidade de instalação ocorreu apenas no dia 15 de maio de 1958 no salão nobre do Grupo Escolar onde iniciou suas atividades e permaneceu entre os anos de 1958 e 1959. Naquele mesmo ano pelo Decreto ${ }^{\circ}$ 20.226, de 22 de novembro de 1958, passou a denominar-se Escola Normal Secundária Dr. Leôncio Correia. Mais tarde, Escola Normal Colegial Estadual Dr. Leôncio Correia até sua desativação no final da década de 1970 (LEMIECHEK, p. 143, 2014).

No ano de 1960, os primeiros 11 normalistas estavam formados e era fato que, inicialmente, as famílias de maior poder aquisitivo foram as principais beneficiadas por ela. De acordo com Lemiechek "eram filhos e filhas de famílias tradicionais e pioneiras no município e muitas das normalistas já estavam casadas, eram mães e exerciam atividade docente no Grupo Escolar Tiradentes ou nas escolas isoladas do município" (p. 143, 2014). Era o caso da 
professora Ondina. Na imagem a seguir, a imponência da antiga construção que abrigou a Escola Normal Colegial Floriano Peixoto e a Escola Normal Colegial Dr. Leôncio Correia, instituições de muita tradição e histórias nas quais a professora Ondina se formou e passou parte de sua vida profissional.

Imagem 3 - Instalações da Escola Normal Colegial Floriano Peixoto e Escola Normal Colegial Dr. Leôncio Correia na década de 1960

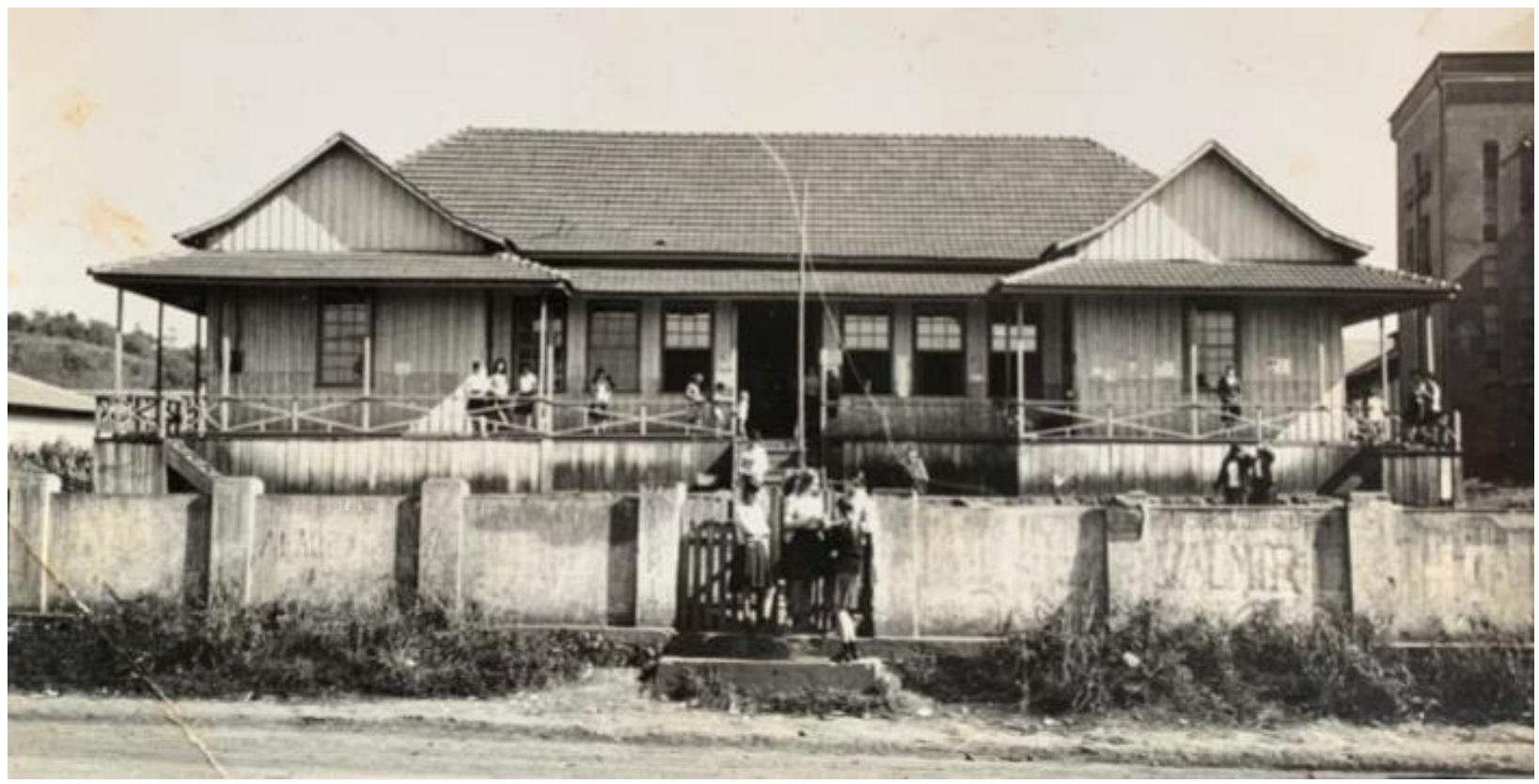

Fonte: acervo da família Folda

Após a conclusão daquele nível de ensino, Ondina passou a ministrar aulas na Escola Normal Secundária onde também exerceu a função de Assistente Técnica o que corresponderia, atualmente, à função de Pedagoga. Atenta às mudanças políticas, sociais e culturais vivenciou, em atividade, a promulgação de leis importantes como a Lei $n^{\circ} 4.024 / 61$ e a Lei $n^{\circ} 5.692 / 71$. Exercendo cargos de destaque como diretora, assistente técnica e chefe da Inspetoria Regional de Ensino, promovia e participava de eventos culturais e educacionais que, muitas vezes, ocorriam durante os finais de semana e, não raro, aconteciam fora do estado do Paraná. Em seu currículo consta a participação em dezenas de eventos de formação pedagógica como o Curso Intensivo de Atualização sobre estudo da Lei 5.692, realizado em Laranjeiras do Sul, em maio de 1975 e organizado pela Secretaria de Educação e Cultura do Estado do Paraná por meio da Faculdade de Filosofia de Palmas e da $46^{\mathrm{a}}$ Inspetoria Regional de Ensino. Esta Inspetoria, da qual Ondina fora chefe por um período, foi criada com outras quatro Inspetorias para atender regiões 
administrativas do Estado do Paraná e funcionaram por décadas, até serem extintas pelo Decreto nº 2.161 de 12 dezembro de 1983, sendo substituídas pelos Núcleos Regionais de Educação.

Imagem 4 - A professora Ondina durante evento de formação pedagógica na década de 1970

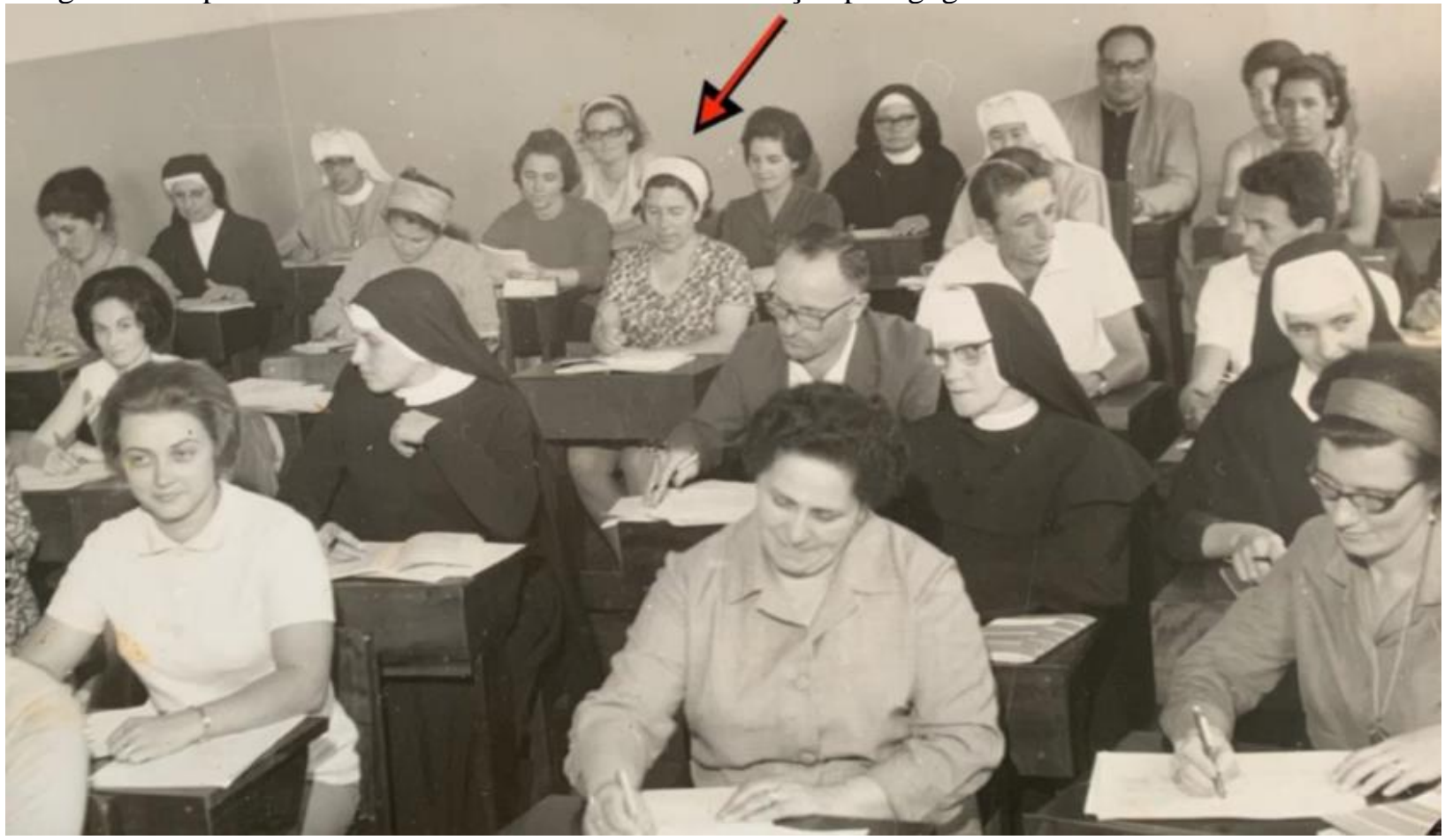

Fonte: acervo da família Folda

Acerca da necessidade constante de aperfeiçoamento e apreço pelos livros e estudos, suas filhas ressaltam

Para melhor preparar-se á nova função, adquiriu a coleção PABBAE e fez a assinatura da Revista Brasileira de Educação [...] Estudando detidamente esses materiais, defrontou-se com as premissas da assim chamada Escola Nova. Desta, soube aproveitar a valorização do lúdico e da criatividade no processo ensino-aprendizagem mas, graças à sua longa experiência, nunca se deixou seduzir pela secundarização do papel do professor. Criava e produzia inúmeros materiais didáticos com os (as) normalistas. Estabelecia explicações detalhadas, mas não enfadonhas, de conteúdos tidos como difíceis, promovendo a paixão e a intimidade do aluno com o conhecimento. Compreendia que para bem ensinar era preciso saber bem. [...] Estudou, como autodidata, importantes pedagogos e pedagogas da modernidade tais como: Rousseau, Pestalozzi, Dewey, Montessori, Anísio Teixeira, entre outros (FOLDA, DETZEL e KLEIN, p. 08, 2020).

No início dos anos 1960, a Escola Normal Ginasial Floriano Peixoto foi perdendo sua importância e diminuindo o número de matrículas por dois motivos. O primeiro é que o Ginásio 
Estadual de Laranjeiras do Sul, em atividade desde fevereiro de 1957, se apresentava como uma opção para quem desejava cursar o ginasial sem realizar as disciplinas características de um curso de formação docente. O segundo motivo é que a Escola Normal Colegial oferecia nível de formação mais elevado sem precisar, necessariamente, passar pelo Curso Normal Regional. Havia ainda a questão legal pois a Lei $n^{\circ}$ 4.024/61 acabara com a formação de normalistas neste nível. No entanto, Laranjeiras do Sul demorou a adaptar-se à legislação e a escola continuou com suas atividades até o final da década quando, em dezembro de 1967, o governador assinou o Decreto ${ }^{\circ} 8.142$ extinguindo a formação normal em nível ginasial da Escola Normal Regional Floriano Peixoto. No ano seguinte, quando a escola ofertava apenas o nível ginasial de caráter propedêutico, a professora Ondina passou a exercer o cargo de diretora até 1976.

Quanto à Escola Normal Colegial Dr. Leôncio Correia, de acordo com Tanuri

O curso normal então disponível começava a se descaracterizar como instância adequada para a formação do professor das séries iniciais, processo esse que se acentuaria progressivamente com as mudanças decorrentes da legislação do regime militar e com a deterioração das condições de trabalho e de remuneração que acompanharam o processo de expansão do ensino de primeiro grau (2000, p. $80)$.

Assim, a Lei de Diretrizes e Bases n 5.692/71 havia determinado que "Art.30 - 92 Exigir-se-á como formação mínima para o exercício do magistério: a) no ensino de $1^{\circ}$ grau, da $1^{\text {a }}$ a $4^{\mathrm{a}}$ séries, habilitação específica de $2^{\circ}$ grau” (BRASIL, Lei no 5.692, 1971). O Paraná implantou gradativamente a nova lei e, numa reorganização de instituições, o Colégio Professor Gildo Aluísio Schuck - Ensino de $1^{\circ}$ e $2^{\circ}$ Graus passou a oferecer a habilitação em Magistério a partir do ano de 1978. Assim, não houve mais novas matrículas e o Curso Normal Colegial formou sua última turma em 1980.

No início da década de 1970, a interiorização do Ensino Superior ainda se mostrava bastante incipiente em todo o país. Para os estudantes de Laranjeiras do Sul e região a conquista do diploma de Graduação só se realizaria com muito sacrifício pessoal e familiar implicando gastos com deslocamento para municípios distantes, além de desgaste emocional e físico, conforme relato a seguir.

Por um ano, a Professora Ondina acompanhou, preocupada, as dificuldades que a filha Lígia Regina e várias ex-alunas normalistas enfrentavam para cursar o Ensino Superior na cidade de Palmas/PR, que distava $196 \mathrm{~km}$ de Laranjeiras do Sul. A preocupação, entretanto, em vez de levá-la à resignação, cutucou sua rebeldia e ela, incontinenti, prestou vestibular para o Curso de Letras PortuguêsFrancês na Faculdade de Filosofia, Ciências e Letras de Palmas, no município 
homônimo, estado do Paraná. Aprovada, seguia com as jovens estudantes, viajando em um fusca, animando o grupo com canções de Villa-Lobos e suas histórias de vida (FOLDA, DETZEL e KLEIN, p. 20, 2020).

Assim, realizando um desejo há muito acalentado e, com um trabalho de conclusão de curso que abordava a Semana de Arte Moderna, Ondina concluiu o curso de graduação no dia 28 de dezembro de 1976.

\section{Para além das atividades do magistério}

Um dos traços marcantes de sua personalidade foi o espírito de mentora intelectual que lhe era muito singular. Para qualificar as atividades pedagógicas que ocorriam em sala de aula e, valorizando o conhecimento de forma sui generis num movimento que ultrapassava os limites da sala de aula, suas ações se configuravam um terreno fecundo que contribua para a formação moral e intelectual de jovens e adultos por meio da ampliação e aprofundamento de saberes.

Miguel, ao propor uma discussão sobre a função do professor enquanto intelectual o faz numa perspectiva gramsciana de intelectual tradicional e intelectual orgânico e também à luz dos estudos de Dermeval Saviani. Em sua reflexão, a autora pondera:

O professor tem aqui um papel relevante, o de ser aquele que possibilita o acesso do aluno ao saber elaborado. Dependendo do trabalho pedagógico que realizar, das possibilidades que criar para seus alunos, poderá elevá-los culturalmente ou deixá-los à mercê do senso comum, impossibilitando-os de apropriarem-se de parte da herança cultural a que têm direito (2016, p.59).

Mesmo passando por momentos de repressão e cerceamento de direitos civis individuais e coletivos, Ondina mantinha-se totalmente engajada nas atividades culturais e educacionais no município e, enquanto orientava, ensinava e aprendia. Participou da fundação e foi a primeira presidente do Grêmio Filhas do Oeste que se configurava uma ala feminina do Clube Operário de Laranjeiras do Sul. De acordo com a família

O Grêmio era constituído apenas por mulheres e atuava de forma colaborativa com o Clube. Entre as atividades recreativas, esportivas e culturais que foram promovidas, o feito de que Ondina mais se orgulhava, na sua gestão, foi a criação de uma Biblioteca, iniciada com a aquisição das coleções Tesouro da Juventude e Clássicos Jackson, ambas da Editora W. M. Jackson Inc.[...] Sobre a qualidade da coleção Jackson, ressalte-se que contemplava autores que iam de Horário e Ovídio a Shakespeare, passando por Xenofonte, Baudelaire, e muitos outros, proporcionando, a quem se dedicasse à sua leitura, uma formação clássica invejável (FOLDA, DETZEL e KLEIN, p.6, 2020). 
No ano de 1963, Ondina fundou o Grêmio Gabriela Mistral. O nome foi homenagem à poetisa, escritora, educadora, diplomata e feminista chilena Lucila de María del Perpetuo Socorro Godoy Alcayaga, ganhadora do Nobel de Literatura de 1945 que usava este pseudônimo. Dentre as atividades do Grêmio, destacamos a organização de times femininos de voleibol, basquetebol e handebol. Mas, o Grêmio configurou-se também um espaço de luta contra a repressão originada do golpe militar de 1964 e a perseguição sofrida pelos cidadãos da região com violência e prisões. De forma geral

$[\ldots]$ os moradores dos núcleos urbanos, em regra, não compreendiam as causas das perseguições e advogavam que "só tinha problemas com os 'milicos' quem tinha 'aprontado' alguma coisa". Inconformada com esses eventos e com a desinformação da população, a professora Ondina Folda coordenou uma atividade junto ao Grêmio Estudantil Gabriela Mistral - da Escola Normal Regional Floriano Peixoto - entre cujos integrantes se encontravam filhos e filhas de muitos dos presos ou perseguidos, que consistiu em estudos, debates e, finalmente, na elaboração e distribuição de um Manifesto que elucidava a questão da Revolta dos Posseiros e os conflitos que levaram ao Golpe de 1964. O manifesto concluía com um apaixonado apelo pela liberdade dos presos e pela volta da democracia. Para a impressão do Manifesto, a professora Ondina adquiriu, as suas próprias custas, um mimeógrafo a tinta. Os gremistas imprimiam as páginas e penduravam-nas em um varal para secar. Saíam, em grupo, à noitinha, postando as páginas sob as portas das casas (FOLDA, DETZEL e KLEIN, p.13, 2020, aspas no original).

Dos memoráveis professores do município ressaltamos o gaúcho Jorge Barreiro. Segundo Lemiechek (2014), Barrreiro era bacharel em Direito e foi professor secundário, redator do jornal O Independente e vereador pelo antigo Movimento Democrático Brasileiro (MDB). Faleceu no dia 25 de dezembro de 1968 em decorrência de acidente automobilístico no Rio Grande do Sul. Logo após seu passamento, a professora Ondina criou o Clube de Civismo Professor Jorge Barreiro que possuía cunho literário e configurava-se um espaço para atividades de pesquisa sobre escritores e poetas brasileiros, produção de contos, crônicas, poesias e momentos de declamação (FOLDA, DETZEL e KLEIN, 2020). 
Imagem 5 - Normalistas da Escola Normal Colegial Dr. Leôncio Correa representam o Clube de Civismo Professor Jorge Barreiro em desfile cívico de 7 de setembro

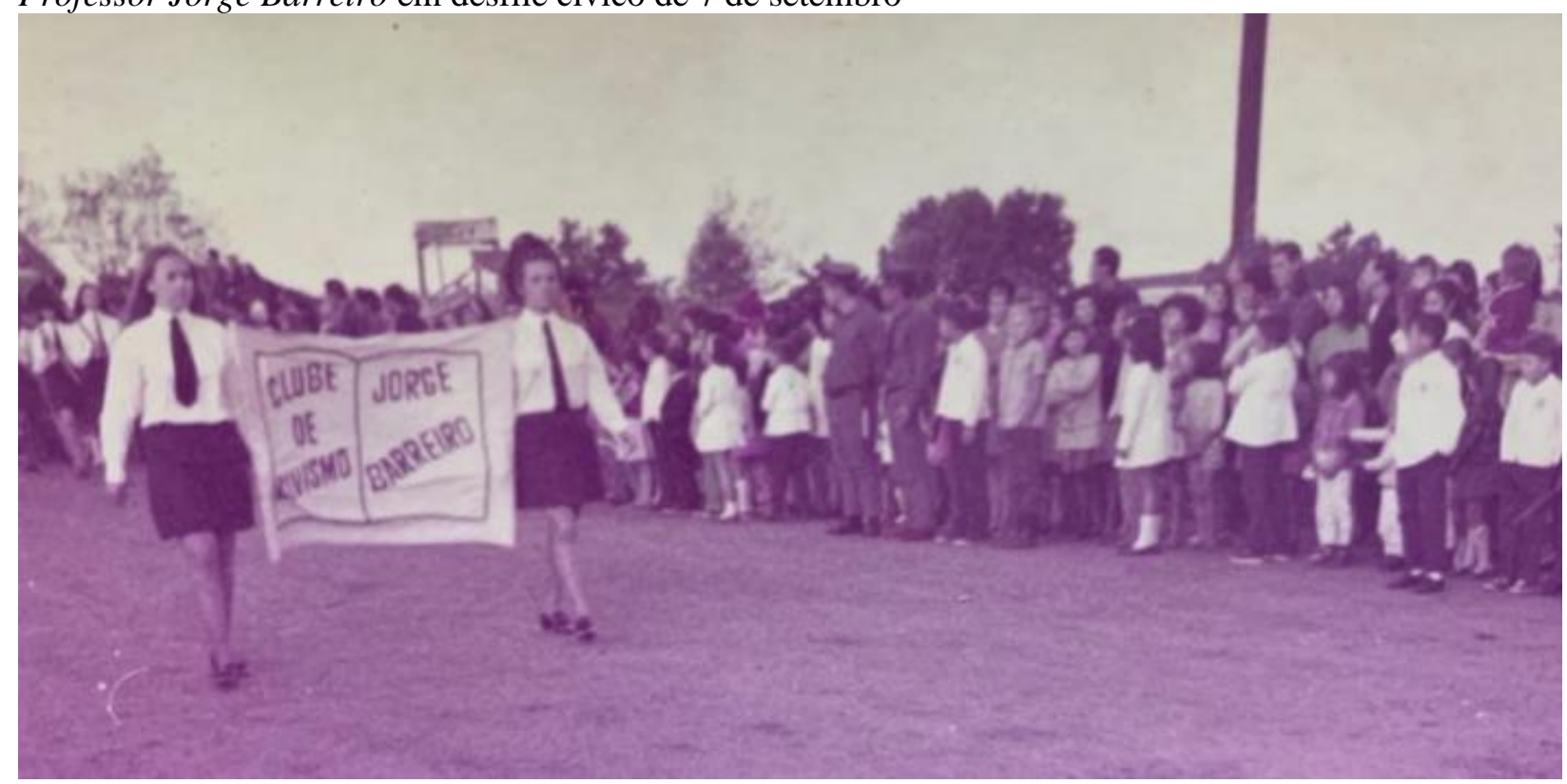

Fonte: acervo da família Folda

Ondina promoveu o teatro estudantil amador, com apresentações semestrais regulares. Incentivou e amparou a criação do jornal estudantil A Palavra e possibilitou a criação do Coral das alunas da Escola Normal Colegial Dr. Leôncio Correa convidando a maestrina Zaida Mussack a dirigi-lo. Em uma ocasião, em um evento com a presença de autoridades do estado do Paraná organizou uma apresentação e

[...] esperando algo enfadonho e amador, o chefe da delegação solicitou que apenas uma canção fosse apresentada. Porém, ao final da primeira interpretação e com os efusivos aplausos pela belíssima apresentação, o chefe da delegação pediu mais canções e assim foram apresentadas todas as que haviam sido ensaiadas, e a plateia pediu mais, para o encantamento de todos (FOLDA, DETZEL e KLEIN, p.19, 2020).

Procurava, com criatividade e esmero, atribuir sentido às datas comemorativas. Não media esforços na organização da Escola Normal Colegial para os desfiles cívicos, trabalhando em temas importantes e preparando magistralmente os pelotões que encenavam passagens históricas. Tais desfiles eram abrilhantados pela presença da fanfarra da Escola Normal e, pessoalmente, cuidava dos detalhes: a escolha dos instrumentos, vestuário e ensaios sempre incentivando os jovens músicos. 
Imagem 6 - Fanfarra da Escola Normal Dr. Leôncio Correia em concentração para desfile cívico de 7 de setembro de 1969

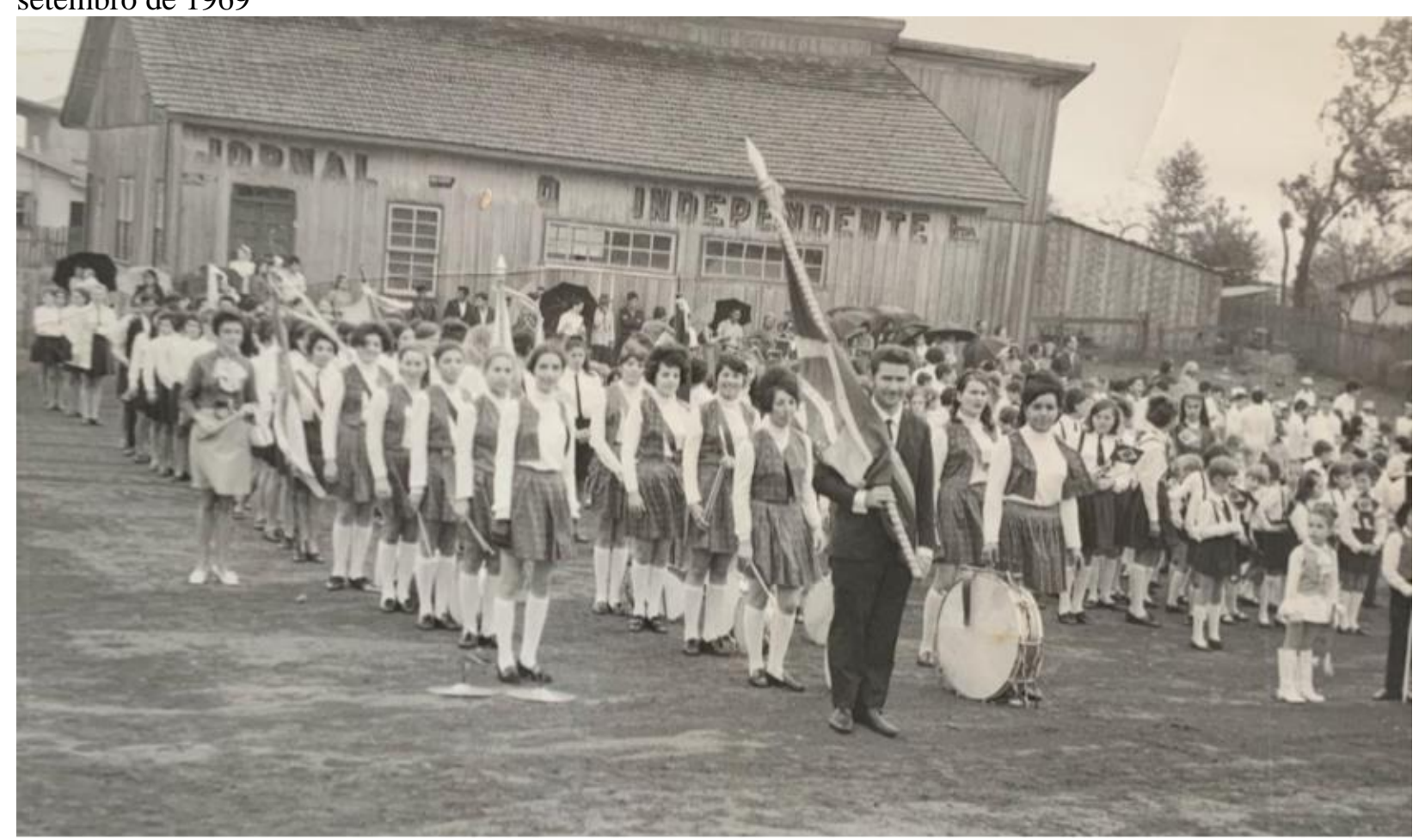

Fonte: acervo da família Folda

Conhecedora das restrições a que eram submetidos os moradores da isolada Laranjeiras do Sul, que carecia de atividades culturais como teatro, museus e parques, a professora Ondina organizava viagens de estudo para as turmas de formandos. Assim, anualmente, fazia excursões para que os alunos pudessem conhecer uma cidade turística e também a capital do Estado.

Com seu companheiro, Thadeu, hospedou e amparou estudantes provenientes da zona rural oportunizando-os o acesso à educação formal. Além da preocupação com os jovens, havia o cuidado com as escolas pois compreendia que cada aluno que estivesse fora da escola ou dela se evadisse aumentaria a possibilidade do fechamento de estabelecimentos em um município já com muitas deficiências e pouco investimento na área educacional.

Num contexto e época onde era massivo o número de analfabetos, Ondina ministrava, diariamente, aulas noturnas para jovens e adultos em uma das salas da Escola Normal Colegial Dr. Leôncio Correia.

\section{O adeus a Laranjeiras do Sul e a aposentadoria: em constante movimento e aprendizado}


Para esta última seção, que reflete sobre o entusiasmo da professora Ondina para o aprendizado ao longo de sua vida, utilizaremos como fonte principal, o dossiê organizado pelas irmãs Folda em fevereiro de 2020.

O ano de 1978 marcou a partida da professora Ondina do município de Laranjeiras do Sul. A solicitação de sua transferência para Curitiba foi motivada pelo ingresso da filha caçula, Lorena Carmen, no antigo Segundo Grau (atual Ensino Médio). Na época, o município não ofertava curso com características propedêuticas visando preparar os alunos para processos seletivos (vestibulares) e consequente ingresso nas diferentes áreas do ensino superior.

Mudando-se para a capital, Ondina passou a lecionar no Bairro Santa Felicidade. Inicialmente no Colégio Estadual Professor Francisco Zardo e, no ano seguinte (1979), no Colégio Estadual Santa Felicidade onde trabalhou até sua aposentadoria3 no ano de 1981.

O início da década de 1980 foi marcado por uma grande provação: um câncer exigiu tratamento radioterápico numa época em que os avanços da medicina ainda não eram tão promissores. Tal tratamento foi eficiente, no entanto bastante agressivo, causando sequelas que anteciparam sua aposentadoria, por invalidez, após mais de 40 anos de atividades no magistério. Porém, este fato não a impediu de continuar sua busca pela aprendizagem e socialização desses conhecimentos. Parcialmente recuperada, dedicou suas tardes para atendimento a pessoas com tendências suicidas, atuando como voluntária no Centro de Valorização da Vida (CVV) durante 2 anos.

Em 1982 iniciou curso de Língua Inglesa que concluiria em março de 1984 e, entre as décadas de 1990 até meados da década de 2000, praticou conversação nesse idioma recebendo aulas particulares semanais em casa.

Ainda no ano de 1982 passou a ministrar aulas particulares de Língua Portuguesa e de Matemática para alunos do Ensino Fundamental. No ano seguinte, iniciou estudo de piano, uma de suas paixões até o final da vida. Desde que aprendeu dedilhar o instrumento até executar com perfeição as canções Quão Grande És Tu (Boberg), Jesus Alegria dos Homens (Bach) e Ave Maria (Gounod), a primeira ação do dia era se dirigir ao piano e executá-las como forma de oração e louvor a Jesus, num agradecimento pela vida.

3 Em 1953, Ondina Folda foi aprovada em um concurso em nível federal e trabalhou como servidora dos Correios. No entanto, esta função administrativa não se mostrou atrativa e ela solicitou exoneração dois anos depois. Sua carreira profissional foi, assim, consolidada no magistério. 
Imagem 7 - Ondina Folda na década de 1990 durante uma de suas audições de piano

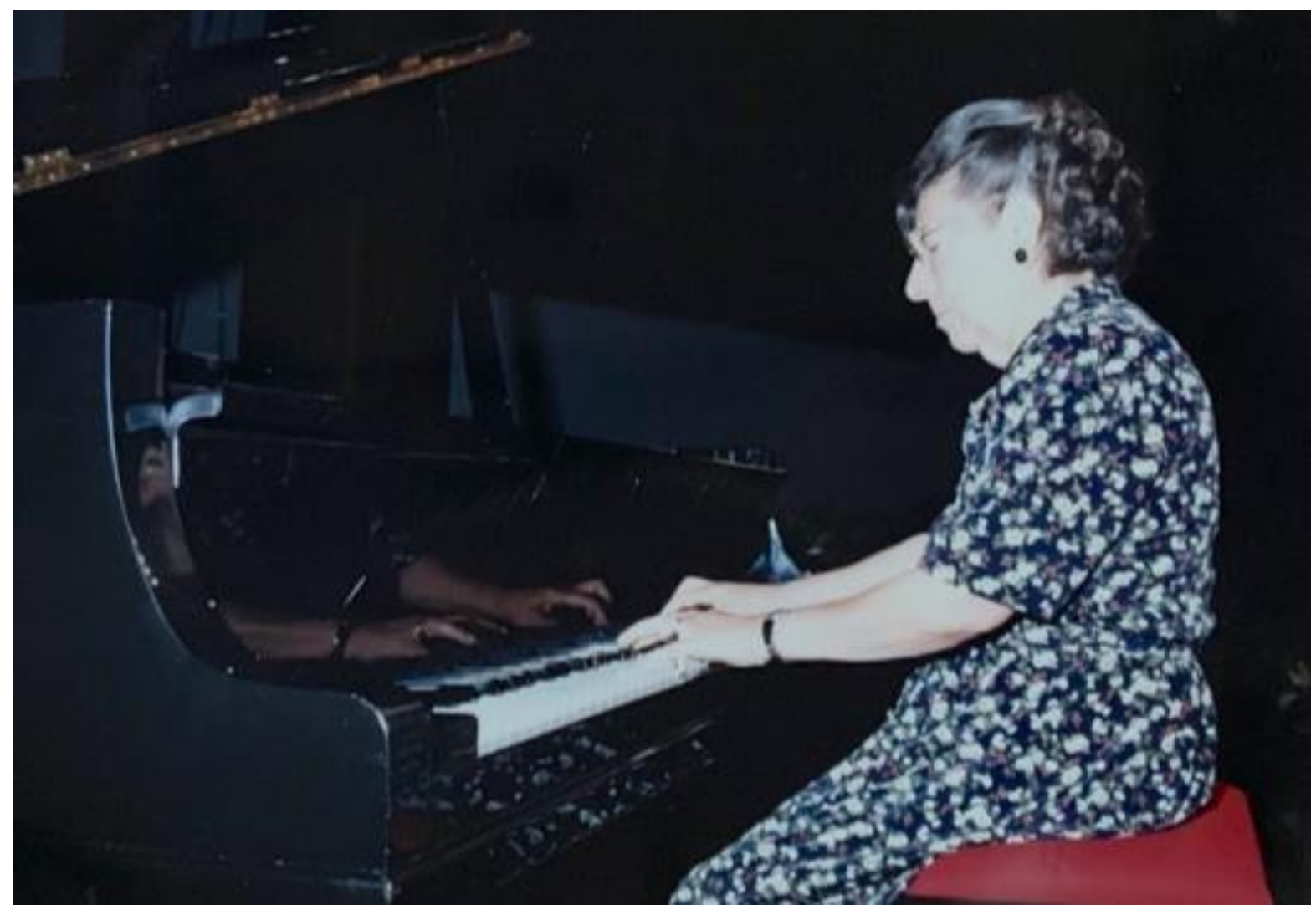

Fonte: acervo da família Folda

No início da década de 1990, passou a praticar aulas de Tai Chi Chuan no Parque Barigui em Curitiba e, mais tarde, também Yoga, em centro especializado. No ano de 1993 faria sozinha, aos 70 anos, uma longa viagem pela Europa revendo amigos e conhecendo novas culturas e a arte que tanto prezou ao longo da vida.

No ano de 2001, iniciou, aos 77 anos, o Curso de Língua e Cultura Italiana no Circolo Vicentini nel Mondo di Curitiba e, ao concluí-lo, aos 80 anos, no dia 05 de dezembro de 2003, recebeu a Declaração de Conclusão das mãos do então Cônsul Geral da Itália em cerimônia de formatura, bem como homenagem especial por não ter faltado às aulas e pelas excelentes notas.

Em 2005, em companhia de amigas, passou a frequentar aulas de Francês, língua com a qual teve grande intimidade na faculdade. $\mathrm{O}$ grupo dividia momentos de passeios e excursões entre outras atividades culturais. Em 2007 inquieta e preocupada com os rumos da sociedade, ingressou no grupo ativista Amigos da Natureza realizando ações e projetos relacionadas à gestão de resíduos sólidos e recursos hídricos da comunidade onde vivia, o Jardim Vergínia III. 
No ano de 2017 a saúde debilitada culminou com seu falecimento, aos 94 anos de idade, no dia 11 julho. Durante a última década de vida, enquanto a visão ainda lhe permitia, continuou realizando atividades costumeiras como as caminhadas, Yoga, Tai Chi Chuan, leituras, estudos de línguas e de música, além da prática do voluntariado. Morreu da forma como viveu seus 94 anos: lúcida e ativa.

Depois de sua partida para Curitiba, a professora voltaria ao município de Laranjeiras do Sul inúmeras vezes para visitar familiares, amigos, colegas de trabalho e ex-alunos e também para receber homenagens. No ano de 1982 foi agraciada com o Título de Cidadã Honorária oferecido pela Prefeitura Municipal como forma de gratidão pelos relevantes serviços prestados à educação. No dia 31 de janeiro de 2009 recebeu homenagem durante encontro de ex-alunos e professores da Escola Normal Colegial Dr. Leôncio Correia promovido na Casa da Amizade. No ano de 2012, recebeu Moção de Reconhecimento da Câmara Municipal de Laranjeiras do Sul, pelo pioneirismo e relevância dos serviços educacionais prestados ao município.

\section{Considerações finais}

Ao final deste texto em que buscamos refletir estabelecendo relações entre a vida profissional da professora Ondina Pereira Folda e a sociedade laranjeirense, entre as décadas de 1940 a 1980, concluímos que a teia das relações humanas foi por ela sabiamente tecida a ponto de sua história emaranhar-se na história educacional do município. Esta relação se solidificou de tal modo que seria impossível construir um conjunto de conhecimentos acerca da educação municipal sem citar seu legado. Diante do histórico apresentado, denota-se que, em um texto conciso, não seria possível esgotar a singularidade e complexidade de uma vida. Então, buscouse unir fragmentos de uma existência tão plena, significativa e permeada de sensibilidade sobre o social, oportunização à educação e fomento a experiências educativas dentro e fora da sala de aula.

Suas escolhas pessoais e profissionais incidiram diretamente na qualidade da educação ofertada no município de Laranjeiras do Sul. Ondina compreendeu e exerceu, com maestria, o seu papel na sociedade em que viveu: foi protagonista. Honrando o posto de educadora que lhe fora outorgado, por meio de concursos públicos, dedicou sua vida à educação deixando um legado de estímulo ao saber, à arte, à cultura e a valorização do conhecimento. Intelectual, Ondina olhou para a realidade a sua volta, estudou e promoveu o desenvolvimento educacional no município de Laranjeiras do Sul enraizando-se na memória coletiva como referência na área. 
Encontrou, no magistério, uma maneira de desenvolver sua intelectualidade participando da criação de escolas, lecionando para crianças, jovens e adultos, questionando, debatendo e difundindo ideias que alicerçavam os projetos de sociedade e educação a partir dos anos 1940.

Enfim, o presente artigo biográfico da professora Ondina Pereira Folda, ao permitir reflexões acerca da História dialogando com a Educação - contextualizando aspectos culturais, sociais e econômicos -, buscou preservar a história e a memória da educadora, ao mesmo tempo que permite ampliar a compreensão acerca da História da Educação.

\section{Referências}

BRASIL. Lei $\mathbf{n}^{\circ}$ 5.692, de 11 de agosto de 1971. Fixa as Diretrizes e Bases da Educação Nacional para o ensino de $1^{\circ}$ e $2^{\circ}$ graus.

Decreto-Lei $n^{0}$ 8.530, de 2 de Janeiro de 1946. Lei Orgânica do Ensino Normal. Disponível em: <http://www2.camara.leg.br/legin/fed/declei/1940- 1949/decreto-lei-8530-2janeiro-1946-458443-publicacaooriginal-1-pe.html>. Acesso em: 28 de fev. De 2019.

Território Federal do Iguaçu. Relatório de atividades do Governador Frederico Trotta encaminhado para o presidente Eurico Gaspar Dutra em 1946. Rio de Janeiro: Imprensa Nacional, 1947.

BORGES, Vavy Pacheco. Grandezas e misérias da biografia. In: Fontes históricas. Carla Bassanezi Pinski (organizadora) - 2.ed., 1ª reimpressão - São Paulo: Contexto, 2008.

FOLDA, Laura; DETZEL, Lorena Carmen; KLEIN, Lígia Regina. Dossiê: Professora Ondina Pereira Folda - Linha do tempo...de um tempo de muita luta pela da educação. 2020.

FOLDA, Ondina Pereira. Entrevista. [mai. 2014]. Curitiba, Paraná. 2014. (2h 16min 46s). Entrevista.

LEMIECHEK, L. Aspectos históricos da formação de professores normalistas no município de Laranjeiras do Sul -PR (1946 -1980). Francisco Beltrão: Universidade Estadual do Oeste do Paraná -UNIOESTE. Dissertação de mestrado, 2014.

LOPES, Sergio. O Território do Iguaçu no contexto da "marcha para oeste". Cascavel. Edunioeste, 2002.

MIGUEL, Maria Elisabeth Blanck. "Intelectual” enquanto atributo do professor. In: História da Educação, Intelectuais e Instituições Escolares / João Carlos da Silva; Eraldo Leme Batista; José Luis Sanfelice. Uberlândia: Navegando Publicações, 2016.

TANURI, Leonor Maria. História da formação de professores. Revista Brasileira de Educação, $n$ 14, mai/jun/jul/ago.2000.

Recebido em 08/05/2020 - Aprovado em 20/06/2020. 